Rev. salud pública. 14 (1): 28-40, 2012

\title{
The cost of connecting poor households to natural gas in Colombia and its impact on health, 2007
}

\author{
Impacto en la salud y el costo de conexión de gas natural \\ domiciliario en los hogares pobres en Colombia, 2007
}

\author{
Nelson Alvis-Guzmán ${ }^{1}$, Luis Alvis-Estrada² y Fernando de La Hoz ${ }^{3}$
}

1 Departamento de Investigaciones Económicas y Sociales-DIES Universidad de Cartagena. Colombia. nalvis@yahoo.com

2 Facultades de Medicina y Enfermería Universidad de Cartagena. Colombia, lalvis20@yahoo.com 3 Departamento de Salud Pública. Facultad de Medicina. Universidad Nacional de Colombia. Bogotá. fpdelahozr@unal.edu.co

Received $6^{\text {th }}$ February 2011/Sent for Modification $9^{\text {th }}$ October 2011/Accepted $11^{\text {th }}$ November 2011

\section{ABSTRACT}

Objective Assessing the cost of subsidizing access to household natural gas (HNG) and its impact on the health of about 35,000 poor households (socioeconomic strata 1 and 2) in Colombia, sponsored by a Global Partnership on Output-Based Aid (GPOBA) project.

Methods The following studies were combined: an analysis of secondary data and analysis of databases provided by the Promigas foundation, demographic data from the 2005 DANE census and databases regarding Central Bank economic statistical series; an analysis of the burden of disease estimated from parameters identified in previous studies; an analysis of the cost of the burden of illness and the estimated costs which were avoided by implementing the HNG connections program; and an analysis of the cost effectiveness of the program linking homes to HNG services.

Results The OBA project led to about 4,000 to 5,000 cases of acute respiratory disease (ARD) and 1,200 to 2,300 outpatient cases of chronic obstructive pulmonary disease (COPD) being avoided during the study period; around 1,200 hospitalizations due to ARD and 500 due to COPD were also avoided. Forty-five to 170 deaths (representing about 45,000 to 90,000 disability-adjusted life years (DALY)) were also avoided. The economic cost of the burden of disease arising from ARI and COPD in such scenario without HNG would have been between 10.7 and 23.6 million dollars, whilst HNG led to costs becoming reduced by about $32 \%$. Conclusions This study was a good estimator of the potential impact of the poorest and most vulnerable households gaining universal access to HNG.

Key Words: Respiratory tract disease, chronic obstructive pulmonary disease, fossil fuel, cost-benefit analysis (source: MeSH, NLM). 


\section{RESUMEN}

Objetivo Valorar el impacto sanitario y económico de subsidiar el acceso al Gas Natural Domiciliario (GND) a hogares pobres (estratos socioeconómicos 1 y 2) en Colombia, auspiciado por Global Partnership on Output Based Aid (GPOBA), proyecto OBA.

Métodos Se combinaron los siguientes estudios: a) Análisis de bases de datos secundarios tomadas de Fundación Promigas, censo DANE 2005, y series estadísticas del Banco de la República b) Análisis de carga de enfermedad estimada a partir de los parámetros de estudios previos c) Análisis de costos de la carga de enfermedad estimada y de los costos evitados luego de implementado el programa de conexiones de GND d) Análisis de costo efectividad del programa de conexiones de los hogares al servicios de GND.

Resultados La presencia del proyecto OBA evitaría, durante el periodo de estudio, cerca de 4 mil y 5 mil casos ambulatorio de IRA y entre 1200 y 2300 de EPOC. Además, se evitarían cerca de 1200 hospitalizaciones por IRA y cerca de 500 por EPOC. Igualmente se evitaría entre 45 y 170 muertes que representaría cerca de 45 mil a 90 mil AVAD. Los costos económicos de la carga de enfermedad por IRA y EPOC en el escenario sin GND serían entre 10,7 y 23,6 millones de dólares mientras que con GND los costos se reducirían en cerca de un $32 \%$.

Conclusiones El presente estudio es un buen estimador de los potenciales efectos de la universalización del acceso al GND por parte de los hogares más pobres y vulnerables.

Palabras Clave: Enfermedades respiratorias, enfermedad pulmonar obstructiva crónica, combustibles fósiles, costo efectividad (source: DeCS, BIREME).

$\mathrm{H}$ ealth-related living conditions are an important influence on the economic situation and welfare of everyone in any society, this being particularly true in low-income countries due to the vicious circle of poverty and disease (1). Health is considered stock capital whose product is healthy time which can be used for obtaining money or wages in the market and producing goods in the home or non-market sector (2). The relationship between health risk and poverty has been well-documented (3).

Pollution from biomass smoke is a major risk factor in developing countries (4). Nearly half of the world's households in poor countries continue to use biomass fuel (5-6). Exposure to biomass smoke has been associated with low birth weight, acute respiratory infections and infant mortality and, more recently, with children's anaemia and mental retardation (7). Such pollutants (called solid fuel smoke) include respirable particulates, carbon monoxide, nitrogen oxide and sulphur, benzene, formaldehyde, 1,3 butadiene and poly- 
aromatic compounds such as benzoic(alpha)pyrene (8-9). Exposure to such contaminants in households having limited ventilation (in both developing and industrialized countries) is higher in women and children as they stay longer in the house. Related measurements have shown that concentrations of these pollutants are above international (WHO) and national standards (8, 10). The US agency for environmental protection has estimated particulate matter (PM10 and PM2.5) standard concentrations at $150 \mathrm{mg} / \mathrm{m}^{3}$ and $65 \mathrm{mg} /$ $\mathrm{m}^{3}$, respectively (11).

Natural gas combustion is ranked globally as the cleanest traditional industrial fuel; particulate matter emissions meet the highest international standards, without having to invest in gas processing equipment. One of the great advantages of natural gas over other fuels is low combustion emission (12).

Most research on intra-domiciliary environmental pollution has been conducted in developing countries and has been associated with determining pollutants and their sources (13). Smith et al., 2004, proposed using exposure-response epidemiological studies conducted outside houses and measuring pollutant concentrations for estimating what happens inside them (14). This model has been used for estimating solid fuel use in sub-regions around the world (14). The population using solid fuel in the American sub-region, including Colombia (AMR-B), was estimated at $24.6 \%$ (18.8-30.8 CI). This means that about a quarter of the Colombian population could be using biofuel. It has been estimated that $2.7 \%$ of all disability-adjusted life year (DALY) are attributed to diseases associated with solid fuel smoke (2.5 \% in men and $2.8 \%$ in women); $32 \%$ occur in Africa (AFR-D), $37 \%$ in southeast Asia (SEAR-D) and $16 \%$ in China, Australia and other countries (WPR-B) (14). Having access to clean fuel paints a different picture regionally and intra-regionally.

Children aged under 5 represent the highest exposure group, although global levels remain unknown (15-16). Many studies have shown a consistent relationship between several diseases and solid fuel use; they have shown that solid fuel smoke causes about $35.7 \%$ of acute respiratory disease (ARD), $22 \%$ chronic obstructive pulmonary disease (COPD) and $1.5 \%$ regarding cancer affecting the tracheae, bronchi and lungs (17).

Furthermore, natural gas represents a health intervention to the extent that it affects household economy and reduces the burden of respiratory diseases in 
the communities in which it is used to improve individual and/or community living conditions (18). The present investigation was aimed at assessing the cost of subsidizing access to household natural gas (HNG) for about 35,000 households (socio-economic strata 1 and 2) in Colombia and its impact on their health; it was sponsored by a Global Partnership on Output-Based Aid (GPOBA) project.

\section{METHODOLOGY}

The following studies were combined to perform the study: a secondary data analysis (a systematic review of the literature) (19) and analysis of databases provided by the Promigas foundation, demographic data from the 2005 DANE census and Banco de la Republica's economic statistical series' databases; an analysis of the burden of disease estimated from parameters identified in earlier surveys in rural areas near the Colombian Caribbean; an analysis of the cost of the burden of illness and the estimated costs avoided by implementing the HNG connections program (20); and a cost effectiveness analysis of households connections to the HNG service (21).

The study was conducted in two phases: estimating the burden of disease (ARI and COPD) associated with biomass smoke in the population being covered by the project at this stage to combine the results of the literature review and estimating the potential economic impact of the subsidized program for connection to the HNG. The estimated population data concerns the projected 2005 DANE census population.

The cost-effectiveness of introducing HNG was analyzed for assessing the economic impact; a decision-tree model was thus developed (Figures 1 and 2) considering two possible scenarios: households without HNG and households having HNG. Both share the possible scenarios in which events can be found elsewhere, for example, patients suffering ARD and /or COPD and without ARD /or COPD. The transition from one event to another was determined by the probability of natural gas coverage and efficiency as a health technology. Assessing the model assumed that people living in homes having natural gas which were not protected against respiratory diseases would be equally likely to suffer respiratory infection caused by other causes and that the effective protection provided by natural gas against respiratory disease would also depend on housing conditions (ventilation of kitchens and independence and efficiency of stoves); similar conditions were assumed for all households. 
Figure 1. ARI choice model

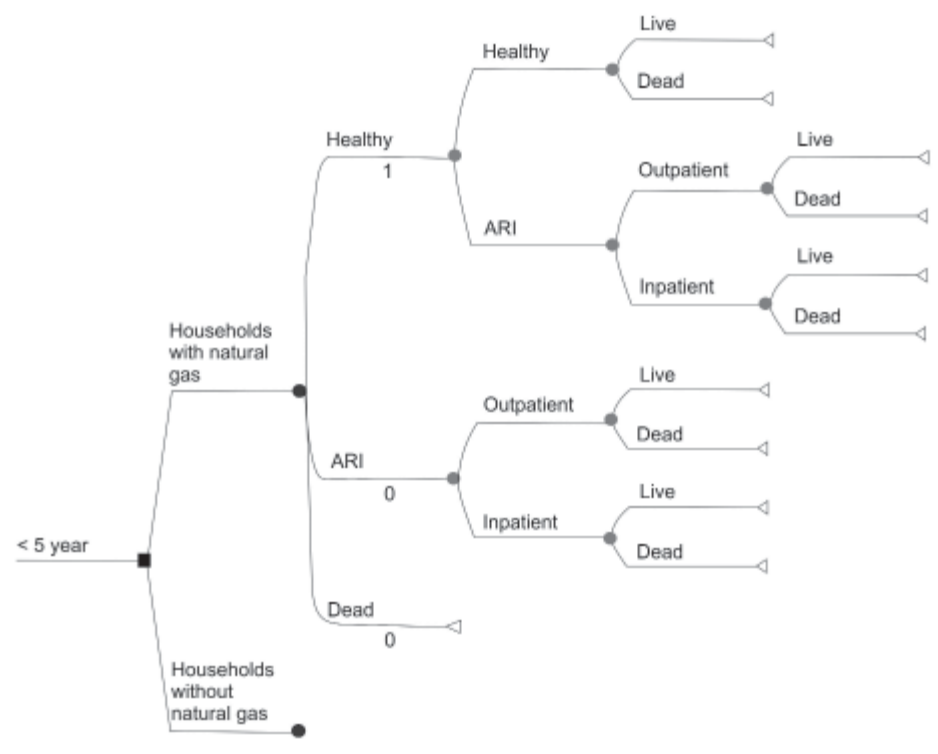

Figure 2. COPD choice model

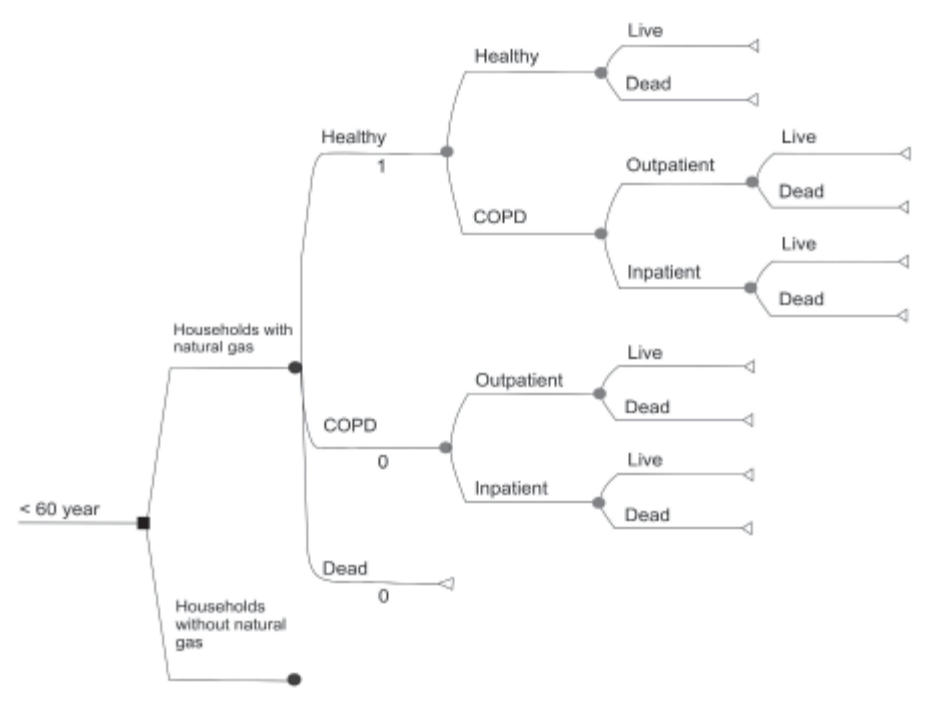


The horizon was 5 years for both children and adults, having a $3 \%$ discount rate for both costs and outcomes. Table 1 gives the model's parameters.

Table 1. Economic assessment parameters for the program regarding the impact of installing household natural gas (HNG)

\begin{tabular}{|c|c|c|c|c|}
\hline \multirow[b]{2}{*}{ Model input } & \multirow{2}{*}{$\begin{array}{l}\text { Base } \\
\text { case }\end{array}$} & \multicolumn{2}{|c|}{ Plausible range } & \multirow[b]{2}{*}{ Source reference } \\
\hline & & $\begin{array}{c}\text { Lower } \\
\text { limit }\end{array}$ & $\begin{array}{l}\text { Upper } \\
\text { limit }\end{array}$ & \\
\hline \multicolumn{5}{|l|}{ Demographics } \\
\hline Households covered by the project & 34,137 & & & \\
\hline Population covered by the project & 143,861 & -- & -- & Current analysis \\
\hline Population under 5 years & 11,940 & -- & -- & Current analysis \\
\hline Population aged 60 & 14,675 & -- & -- & Current analysis \\
\hline \multirow{5}{*}{$\begin{array}{l}\text { Average monthly income per household } \\
\text { Monthly expenditure on fuel other than } \\
\text { HNG } \\
\text { Average monthly expenditure without HNG } \\
\text { subsidy } \\
\text { Average monthly expenditure on subsi- } \\
\text { dized HNG } \\
\text { Discount rate }\end{array}$} & 174 & 137 & 250 & surveys \\
\hline & 9.1 & 8.0 & 10.1 & Surveys \\
\hline & 4.0 & 3.5 & 4.5 & Current analysis \\
\hline & 2.1 & 1.9 & 2.3 & Current analysis \\
\hline & $3 \%$ & & & Current analysis \\
\hline \multicolumn{5}{|l|}{ Odds (cumulative incidence) } \\
\hline Cumulative ARD incidence & 12.6 & 11.5 & 13.5 & (22) \\
\hline Proportion of hospitalization & 30 & 25 & 35 & (18) \\
\hline Proportion of hospital mortality & 4 & 3 & 5 & (18) \\
\hline EPOC prevalence & 8.9 & 7.3 & 13.4 & (23) \\
\hline Proportion of hospitalization & 30 & 25 & 35 & (5) \\
\hline Proportion of hospital mortality & 8 & 5 & 11 & (2) \\
\hline \multicolumn{5}{|l|}{ Effectiveness of gas in avoiding events } \\
\hline ARI effectiveness & 62.7 & 55 & 69 & (surveys) \\
\hline COPD effectiveness & 26.6 & 22 & 31 & (surveys) \\
\hline \multicolumn{5}{|l|}{ Cost (US\$ 2005) } \\
\hline Average cost of hospitalized patients * & 886 & 867 & 1,325 & (22) \\
\hline \multirow{2}{*}{$\begin{array}{l}\text { Average cost of ARI outpatients * } \\
\text { Average cost of COPD patients hospital- } \\
\text { ized* }\end{array}$} & 93 & 78 & 221 & (22) \\
\hline & 5,215 & 4,800 & 5,500 & (24) \\
\hline Average cost of COPD outpatients * & 500 & 450 & 550 & (24) \\
\hline Cost of installing HNG & 146 & 127 & 170 & Current analysis \\
\hline \multicolumn{5}{|l|}{ Weighting disability } \\
\hline Disability weighted for ARI & 0.280 & & & (25) \\
\hline Disability weighted for COPD & 0.334 & & & (25) \\
\hline
\end{tabular}

* Includes direct and indirect costs

The total cost of the burden of respiratory disease associated with biomass smoke, the cost of disease burden averted by the HNG connection grant program where both outpatient (medical) and ARI in hospitalized children and COPD in older adults, deaths from these diseases and the years of disabilityadjusted life years (DALYs) averted were the outcomes measured or result of the program for the model. 
The incremental cost-effectiveness ratio (ICER) was used for comparing alternatives with and without an HNG programme, using the following formula:

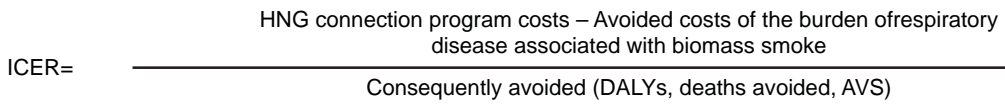

The ICER compared the difference in cost regarding differences in health outcomes in different scenarios. Avoided costs were deducted from the cost of implementing the grant program for cost effectiveness of disease analysis and were divided between health outcomes (life expectancy gained per woman, year of life saved, deaths prevented, etc.). The costs were expressed in dollars and pesos (2008 prices). All future costs and benefits were discounted at an annual $3 \%$ rate and were expressed in US dollars for 2005 for the sensitivity analysis using different assumptions for the parameters.

Moreover, the project's internal rate of return was estimated to assess the investment's profitability, assuming that all households covered by the project received an average \$137 to \$250 per month income, monthly average costs without subsidy would have been $\$ 2.3$ to $\$ 1.9$ and the average monthly subsidy cost would have been $\$ 4.5$ to $\$ 3.5$, all households would have received an HNG installation cost subsidy of $\$ 146$ and all households prior to HNG installation would have consumed various fuels having an average monthly cost of \$10.1 to $\$ 8.0$. Households were followed-up for 20 years and yields were assumed to be constant.

\section{RESULTS}

\section{Project coverage}

The OBA project covered 34,147 poor households in 84 localities in 63 municipalities in 7 of the 34 Colombian departments. The project was mainly focused on the city of Cali in the Valle del Cauca $(40.1 \%$ of the project), covering $22.2 \%$ of households having unmet basic needs (13,404 of the 61,779 potential beneficiaries). By contrast, Caucasia in the Antioquia Department had only 646 households with unmet basic needs (9,972 potential beneficiaries). The Atlántico department had the most locations; 34 located in 16 municipalities covering $9.8 \%$ of households having unmet basic needs. The project had $7.8 \%$ overall coverage of households having unmet basic needs which could potentially have received a grant. The selected departments had 
different levels of development and therefore different levels of poverty. The department having the highest human development index (HDI) was the Valle del Cauca and the Sucre department had the worst HDI; the Valle del Cauca has 2.78 times per capita gross domestic product (GDP) than that of Sucre.

Burden of disease arising from ARI and COPD in the study population The absence of HNG project facilities at the 84 project sites would have led to between 6,288 and 7,382 outpatient cases of ARI occurring and between 2,500 and 500,000 hospitalizations during the 5 years' observation. This could have led to between 47 and 129 deaths and 75,000 to 127,000 DALYs per ARD during the period. Between 5,000 and 9,000 cases of outpatient visits for COPD and 1,200 to 3,152 hospitalizations could have occurred and 61 to 347 deaths from COPD and between 12,000 and 35,000 DALYs.

Table 2 shows that the presence of the OBA project avoided about 4,000 to 5,000 cases of outpatient ARI during the study period and between 1,200 and 2,300 COPD cases. About 1,200 hospitalizations due to ARI and 500 due to COPD were avoided as were 45 to 170 deaths, representing about 45,000 to 90,000 DALYs.

Table 2. Burden of disease in the localities covered by the project. Colombia, 2008

\begin{tabular}{|c|c|c|c|c|c|c|}
\hline \multirow[b]{2}{*}{$(A R I)$ events $<5$ years } & \multicolumn{3}{|c|}{$\begin{array}{c}\text { In the absence of the } \\
\text { OBA project }\end{array}$} & \multicolumn{3}{|c|}{$\begin{array}{l}\text { In the presence of the OBA } \\
\text { project }\end{array}$} \\
\hline & $\begin{array}{l}\text { Base } \\
\text { case }\end{array}$ & $\begin{array}{l}\text { Lower } \\
\text { limit }\end{array}$ & $\begin{array}{l}\text { Upper } \\
\text { limit }\end{array}$ & $\begin{array}{l}\text { Base } \\
\text { case }\end{array}$ & $\begin{array}{l}\text { Lower } \\
\text { limit }\end{array}$ & $\begin{array}{l}\text { Upper } \\
\text { limit }\end{array}$ \\
\hline Outpatient cases & 6,562 & 6,288 & 7,382 & 2,165 & 2,075 & 2,436 \\
\hline Hospitalizations & 1,969 & 1,572 & 2,584 & 650 & 519 & 853 \\
\hline Deaths & 79 & 47 & 129 & 26 & 16 & 43 \\
\hline DALYS & 96,049 & 75,697 & 127,723 & 31,696 & 24,980 & 42,149 \\
\hline \multicolumn{7}{|l|}{$(C O P D)$ events $>60$ years } \\
\hline Outpatient cases & 6,049 & 4,906 & 9,006 & 4,476 & 3,631 & 6,664 \\
\hline Hospitalizations & 1,815 & 1,227 & 3,152 & 1,343 & 908 & 2,332 \\
\hline Deaths & 145 & 61 & 347 & 107 & 45 & 257 \\
\hline DALYs & 19,764 & 12,822 & 35,711 & 14,625 & 9,488 & 26,426 \\
\hline \multicolumn{7}{|l|}{ Total avoided events } \\
\hline Outpatient cases of ARI avoided & & & & 4,068 & 3,899 & 4,577 \\
\hline ARI hospitalizations avoided & & & & 1,220 & 975 & 1,602 \\
\hline ARI-linked deaths avoided & & & & 49 & 29 & 80 \\
\hline ARI-linked DALYs avoided & & & & 59,550 & 46,932 & 79,188 \\
\hline Outpatient COPD cases avoided & & & & 1,573 & 1,276 & 2,341 \\
\hline COPD-linked hospitalizations avoided & & & & 472 & 319 & 820 \\
\hline EPOC-linked deaths avoided & & & & 38 & 16 & 90 \\
\hline EPOC-linked AVAD avoided & & & & 5,139 & 3,334 & 9,285 \\
\hline
\end{tabular}


The project's economic impact

The economic costs of the burden of disease arising from ARI and COPD in a scenario without HNG would range between US 10.7-23.6 million dollars. A scenario involving HNG would reduce these costs by about $32 \%$ (Table 3 ).

The HNG project's incremental cost effectiveness would have been between minus 8,000 (cost savings) and 18,000 dollars to avoid a death, and from under US\$ 16 to US\$ 17 to avoid a DALY. The net cost would have been under 1.4 million dollars (cost savings) to 834,000 dollars in 2005.

Table 3. Costs of the burden of disease in the localities covered by the project. Colombia 2008

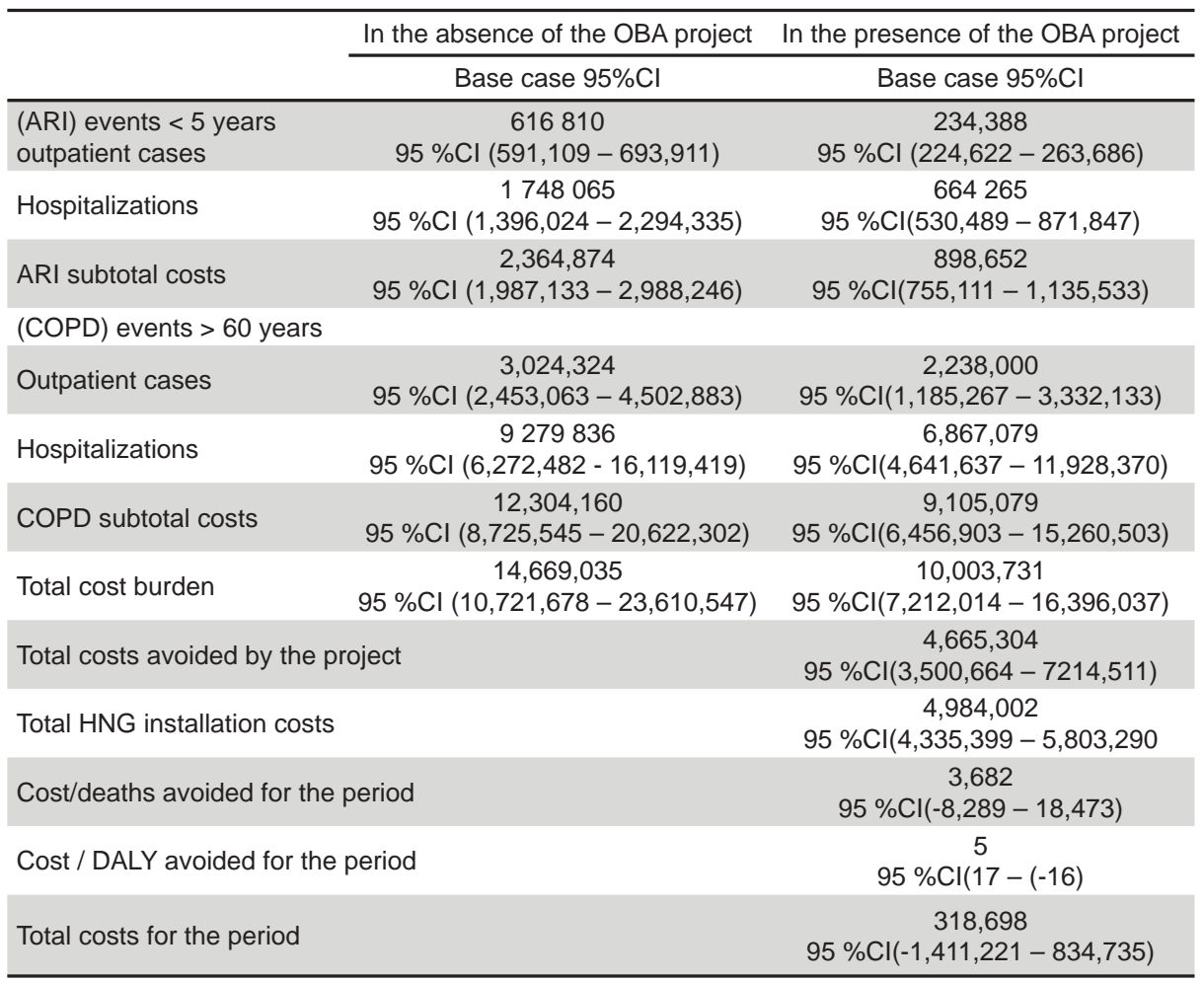

Sensitivity analysis

A sensitivity analysis of the way to display the variables having the greatest incremental impact effect on the cost of connecting homes to HNG gave COPD prevalence, the cost of HNG installation, NDA effectiveness in affecting 
COPD prevalence, the proportion of hospitalizations arising from COPD and the average cost of outpatient and hospital ARD.

Other benefits arising from HNG connection to households were the savings produced by stopping using different fuels which were more than twice more costly than paying the monthly bill if households did not receive subsidies from the state. In the scenario where households received the state subsidy, these costs could have been up to 4 times what the household was paying each month for the service. If it were assumed that these households maintained this condition for about 20 years, then returns on such savings could have produced the initial investment (HNG connection subsidy).

Table 4 gives the internal rate of return for the HNG service connection project for poor households; this would have been between $37 \%$ and $46 \%$ in cases where service consumption was not subsidized and $50 \%$ to $64 \%$ in a scenario involving state subsidies.

Table 4. Financial return of the HNG project for households for 20 years Colombia 2008

\begin{tabular}{lccc}
\hline \multicolumn{1}{c}{ Items } & Average & Lower limit & Upper limit \\
\hline Total household income & $1,096,087,341.3$ & $865,834808.4$ & $1,569,325590.3$ \\
Spending on fuel different to HNG & $57,009,359.7$ & $50,367,234.2$ & $63,652,387.1$ \\
HNG spending without subsidy & $25,109,209.4$ & $21,970,558.3$ & $28,247,860.6$ \\
HNG spending with subsidy & $13,182,335.0$ & $11,926,874.5$ & $14,437,795.4$ \\
State subsidies & $11,926,874.5$ & $10,043,683.8$ & $13,810,065.2$ \\
Savings without subsidies & $31,900,150.3$ & $28,396,676.0$ & $35,404,526.5$ \\
Savings with subsidies & $43,827,024.8$ & $38,440,359.8$ & $49,214,591.7$ \\
Internal rate of return without subsidies & $42 \%$ & $37 \%$ & $46 \%$ \\
Internal rate of return with subsidies & $57 \%$ & $50 \%$ & $64 \%$ \\
\hline
\end{tabular}

\section{DISCUSSION}

There were 9.74 million households in Colombia according to the 2005 DANE census; 3.92 million (40.3 \%) had access to the HNG service. The Colombian Ministry of Mines and Energy reported 4.93 million homes connected to HNG (26) in 2008, representing a growth of more than one million homes in three years, covering over $50 \%$ of all households. This demonstrated the increased risk of ARI, COPD and lung cancer in households cooking with biofuel (27). The limited information in this study only measured the disease burden of ARI and COPD assuming an underestimation of the protective effects of HNG, for example, lung cancer. However, 
as shown, assuming the WHO criteria (3), HNG is a highly cost-effective technology and thus its incorporation into benefits for the social development of poor and marginalized communities is beyond dispute.

This study was thus a good estimator of the potential impact of the poorest and most vulnerable households gaining universal access to HNG, being those which generate the greatest burden of disease by pollution. This investigation provides a means of supporting public policy aimed at impelling decision-makers to mitigate or eliminate pollution or improve the efficiency of stoves, switching from burning biomass to using HNG and thereby reducing the frequency of cases of ARI, COPD and other respiratory diseases and household economy reorientation and improvement (28). Such findings were consistent with CONPES document 3344/2005 setting out guidelines for formulating policy regarding preventing and controlling air pollution (29). It has been estimated that 6,000 deaths, 7,400 new cases of chronic bronchitis (COPD), 13,000 hospitalizations and 255,000 visits to emergency rooms occur in Colombia per year, according to Larson, costing between 230 and 600 billion pesos in 2004 (28).

Incentives are already in place in Colombia (Article 97, Act 142/1994) facilitating the implementation of policy regarding subsidies. The cost of household connection and meters for strata 1, 2 and 3 can be covered by the municipality, department or the nation through budgetary support, but political goodwill is an important input for achieving goals for reducing pollution from biomass smoke (30). However, given the high rates of return for this project (37\% and $46 \%$ when service consumption was not subsidized and $50 \%$ to $64 \%$ in a scenario with state subsidies) it is very difficult to deny such choice

Acknowledgments: This research was financed by the Promigas foundation as part of the Natural Gas Connections Involving Poor Households Project sponsored by the Global Partnership on Output-Based Aid (GPOBA) for 34,137 poor households in 84 localities throughout Colombia.

\section{REFERENCES}

1. Schultz T. Reflections on investment in man. Journal of Political Economy, 1962; 70: 101109.

2. Grossman M. On the concept of health capital and the demand for health. Journal of Political Economy. 1972;80: 223-255. 
3. WHO. Macroeconomics and health: investing in health for economic development. Report of the Commission on Macroeconomics and Health in Commission on Macroeconomics and Health. Geneva: World Health Organization; 2001.

4. Fullerton DG, Bruce N, Gordon SB. Indoor air pollution from biomass fuel smoke is a major health concern in the developing world. Trans R Soc Trop Med Hyg, 2008; 102 (9):843-51.

5. Rehfuess E, Corvalan C, Neira M. Indoor air pollution: 4000 deaths a day must no longer be ignored. Bull World Health Organ. 2006 Jul;84(7):508.

6. Rehfuess E, Mehta S, Pruss-Ustun A. Assessing household solid fuel use: multiple implications for the Millennium Development Goals. Environ Health Perspect. 2006; 114(3):373-8.

7. Mishra V, Retherford RD. Does biofuel smoke contribute to anaemia and stunting in early childhood? Int J Epidemiol. 2007; 36(1):117-29.

8. Smith KR. Biofuels, air pollution and Health: a global review. New York: Plenum Editor; 1987.

9. Pandey MR, Boleij JS, Smith KR, Wafula EM. Indoor air pollution in developing countries and acute respiratory infection in children. Lancet. 1989 Feb 25;1(8635):427-9.

10. Bruce N, Perez-Padilla R, Albalak R. Indoor air pollution in developing countries: a major environmental and public health challenge. Bull World Health Organ. 2000;78(9):1078-92.

11. Agency U.S.E.P. Revisions to the National Ambient Air Quality Standards for Particles Matter. Federal Register; 1997. p. 38651-38701.

12. Innergy Soluciones Energeticas. Ventajas Para el Medio Ambiente [Internet]. Ventajas del Gas Natural 2007. Available from: http://www.innergy.cl/ventajas1.htm Consulted Octubre 2007.

13. Spengler JD, Samet JM, McCarthy JF Indoor Air Quality Handbook. New York: McGraw-Hill; 2001.

14. Smith KR, Mehta S, Feuz M. Indoor smoke from household solid fuels. In: Ezzati M, Lopez AD, Rodgers A, Murray CJL (Eds). Comparative quantification of health risks: Global and regional burden of disease due to selected major risk factors. Geneva: World Health Organization; 2004.

15. Ezzati M, Kammen DM. Quantifying the effects of exposure to indoor air pollution from biomass combustion on acute respiratory infections in developing countries. Environ Health Perspect. 2001 May;109(5):481-8.

16. Saksena S, Prasad R, Pal RC, Joshi V. Patterns of daily exposure to TSP and CO in the Garhwal Himalaya. Atmospheric Environment Part A General Topics. 1992;26(11):2125-34.

17. WHO. Addressing the links between indoor air pollution, household energy, and human health. Meeting report of the WHO-USAID global consultation on the health impact of indoor air pollution and household energy in developing countries. Geneva: World Health Organization; 2002.

18. Alvis N, Alvis L, Orozco J. Costo Efectividad del Gas Natural Domiciliario como Tecnología Sanitaria en Localidades Rurales del Caribe Colombiano. Rev. salud pública (Bogotá). 2008; 10(4):537 - 549.

19. Alvis N, De La Hoz F. Home air pollution and respiratory illnesses (low sharp respiratory infection, COPD, lung cancer and asthma): evidences of association. Rev.fac.med.univ. nal. 2008; 56(1): 54-64.

20. Arredondo A, Damian T. The economic costs in the production of health services: from the cost of inputs to the cost of case management. Salud Publica Mex. 1997; 39(2):117-24.

21. Drummond M. Methods for the economic evaluation of health care programs. Third Edition ed. Oxford GB: Oxford Medical Publications; 2005.

22. SinhaA, Constenla D, Valencia JE, O'Loughlin R, Gomez E, de la Hoz F, et al. Cost-effectiveness of pneumococcal conjugate vaccination in Latin America and the Caribbean: a regional analysis. Revista Panamericana de Salud Pública. 2008;24:304-13.

23. Caballero AS, Torres C, Maldonado D, Jaramillo C, Guevara D. Prevalencia de la Enfermedad Pulmonar Oclusiva Crónica en cinco ciudades colombianas. Revista Médica Sanitas, 2005; Edición Especial. pp 8-27. 
24. Pérez N, Murillo R, Pinzón C, Hernández G. Costos de la atención médica del Cáncer de Pulmón, la EPOC y la IAM atribuibles al consumo de tabaco en Colombia. Rev Colomb de cancerol. 2007; 11(4):241-249.

25. Murray CJL, Lopez A. The Global Burden of Disease. Boston: Harvard University Press; 1986. 26. MinMinas [Internet]. Cobertura del servicio de Gas Natural-IV Trimestre de 2008. 2009 Available from: http://www.minminas.gov.co/minminas/downloads/UserFiles/File/ GAS/COBERTURA_DICIEMBRE_2008_smca.def.pdf Consulted Feb 2009.

27. Norman R, Barnes B, Mathee A, Bradshaw D. Estimating the burden of disease attributable to indoor air pollution from household use of solid fuels in South Africa in 2000. S Afr Med J. 2007 Aug;97(8 Pt 2):764-71.

28. Larson BA, Rosen S. Understanding household demand for indoor air pollution control in developing countries. Soc Sci Med. 2002; 55(4): 571-84.

29. Departamento Nacional de Planeación-DNP. Consejo Nacional de Política Económica y Social República de Colombia 3344: Lineamientos para la formulación de la política de prevención y control de la contaminación del aire. Bogotá D.C; 2005.

30. Alzate M. [Internet]. La estratificación socioeconómica para el cobro de los servicios públicos domiciliarios en Colombia ¿Solidaridad o focalización? Estudios y perspectivas. 2006; 14 . Available from: http://www.eclac.cl/publicaciones/ xml/1/27241/LCL.2604-P.pdf Consulted January 2010. 